\title{
Publisher Correction: TGF- $\beta$ signaling in Th17 cells promotes IL-22 production and colitis-associated colon cancer
}

Laura Garcia Perez, Jan Kempski, Heather M. McGee (D), Penelope Pelzcar, Theodora Agalioti, Anastasios Giannou, Leonie Konczalla (1), Leonie Brockmann, Ramez Wahib (1), Hao Xu, Maria Carolina Amezcua Vesely, Shiwa Soukou, Babett Steglich, Tanja Bedke, Carolin Manthey, Oliver Seiz, Björn-Philipp Diercks D, Stylianos Gnafakis, Andreas H. Guse (D), Daniel Perez, Jakob R. Izbicki, Nicola Gagliani, Richard A. Flavell (1D) \& Samuel Huber (iD)

Correction to: Nature Communications https://doi.org/10.1038/s41467-020-16363-w, published online 25 May 2020

The original version of this article contained an error in Fig. 6d. During typesetting of the accepted paper, the dot plot for the third panel $(0.5 \mu \mathrm{M})$ was duplicated into the second panel $(0.1 \mu \mathrm{M})$. A correct version of Fig. 6 is shown below. The error has now been corrected in the original version of the article.

Published online: 06 November 2020

\footnotetext{
(c) (i) Open Access This article is licensed under a Creative Commons Attribution 4.0 International License, which permits use, sharing, adaptation, distribution and reproduction in any medium or format, as long as you give appropriate credit to the original author(s) and the source, provide a link to the Creative Commons license, and indicate if changes were made. The images or other third party material in this article are included in the article's Creative Commons license, unless indicated otherwise in a credit line to the material. If material is not included in the article's Creative Commons license and your intended use is not permitted by statutory regulation or exceeds the permitted use, you will need to obtain permission directly from the copyright holder. To view a copy of this license, visit http://creativecommons.org/licenses/by/4.0/.
}

(c) The Author(s) 2020 
a

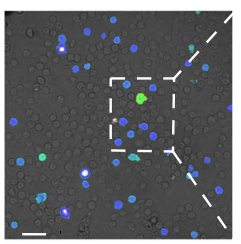

b

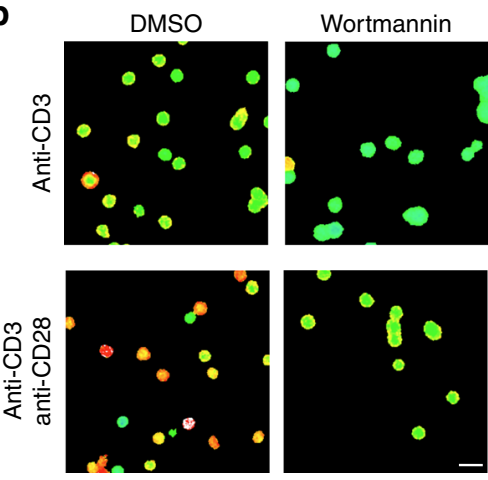

C
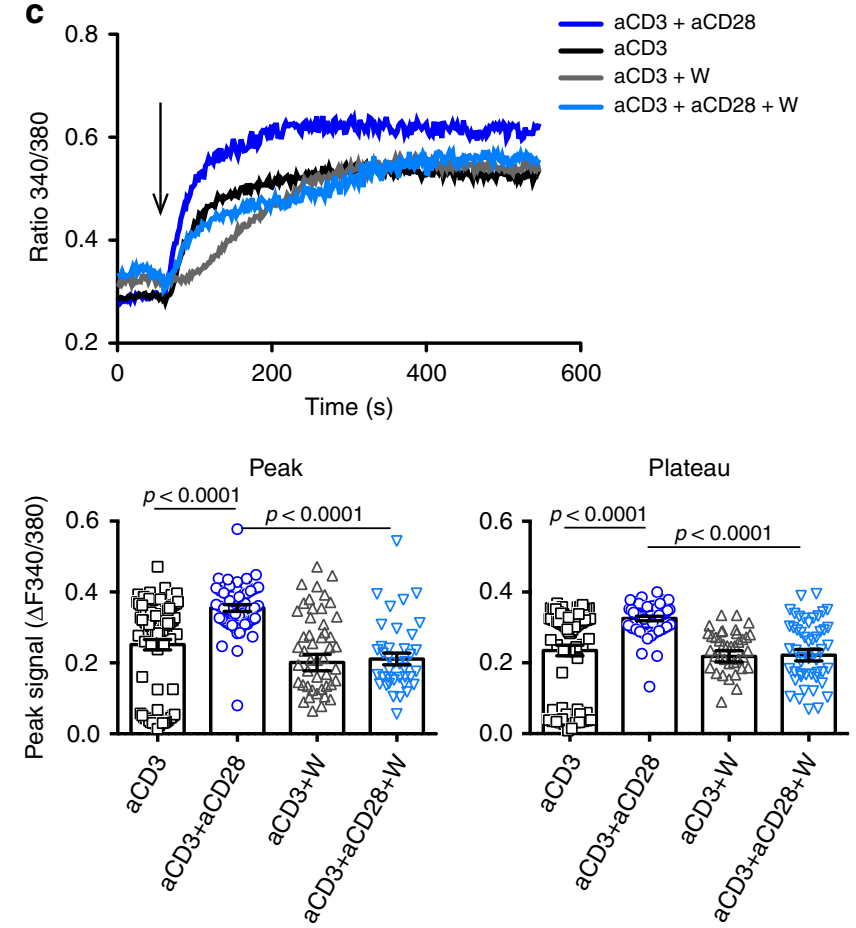

d
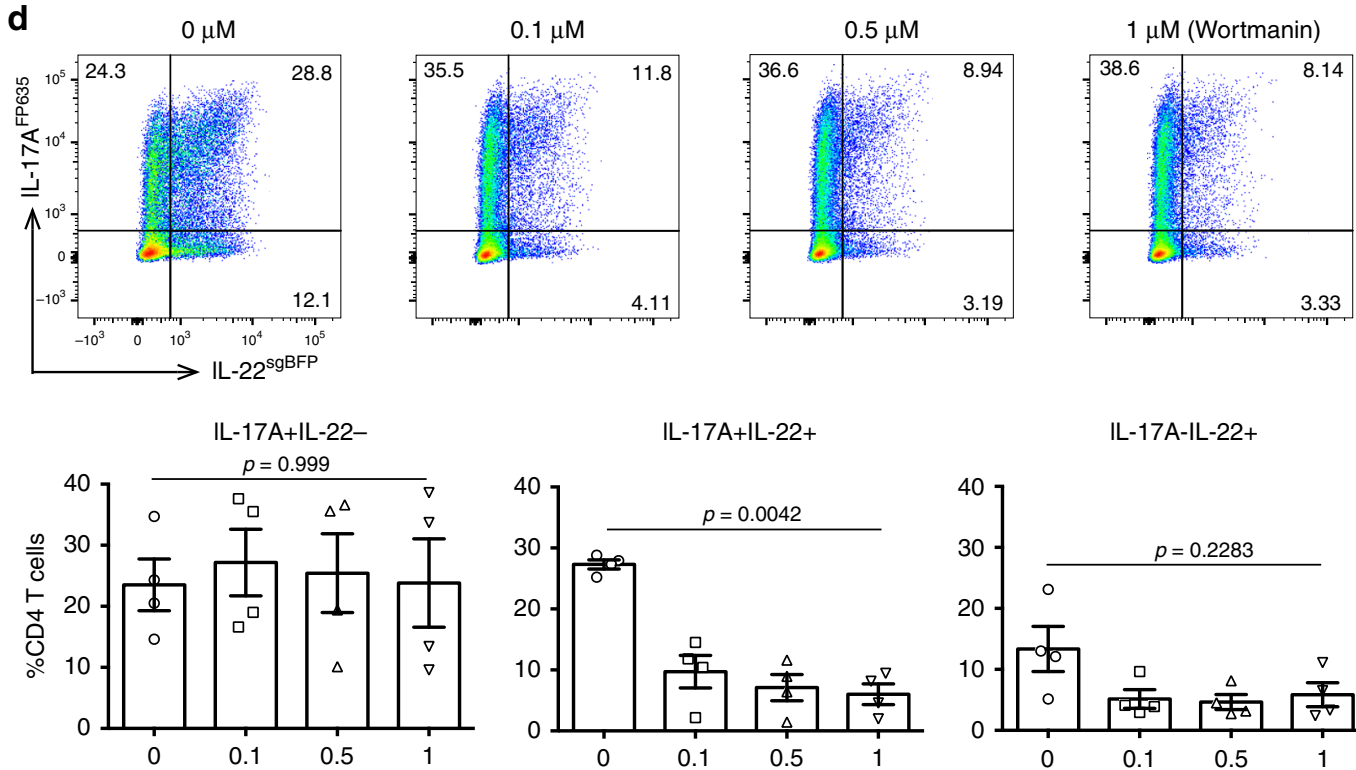

IL-17A+IL-22+

IL-17A-IL-22+
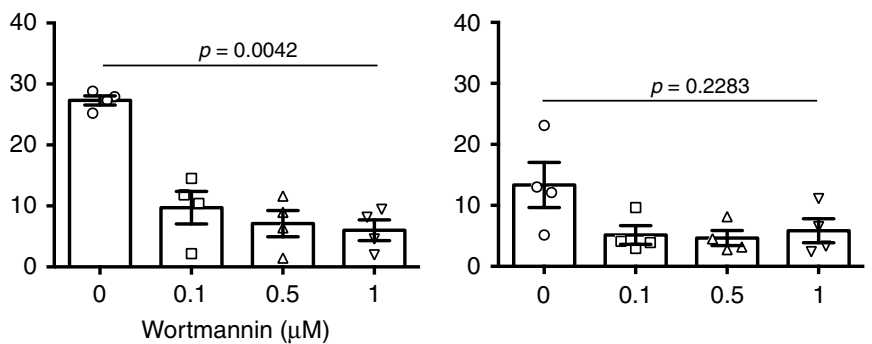

Fig. 6 